\title{
Adenovirus-mediated small interfering RNA targeting tumor necrosis factor- $\alpha$ inhibits titanium particle-induced osteoclastogenesis and bone resorption
}

\author{
HAOHUI GUO $^{1}$, JIAN ZHANG ${ }^{2}$, SHAOWEN HAO ${ }^{1}$ and QUNHUA JIN ${ }^{1}$ \\ ${ }^{1}$ Department of Orthopedic Surgery, Ningxia Medical University Affiliated Hospital, Yinchuan; \\ ${ }^{2}$ Department of Pathology, Xi'an Jiao Tong University Medical School, Xi'an, P.R. China
}

Received December 10, 2012; Accepted March 4, 2013

DOI: $10.3892 /$ ijmm.2013.1416

\begin{abstract}
Wear particles are phagocytosed by macrophages, resulting in cellular activation and the release of pro-inflammatory factors, which cause periprosthetic osteolysis and subsequent aseptic loosening, the most common causes of total joint arthroplasty (TJA) failure. During this pathological process, tumor necrosis factor (TNF)- $\alpha$ plays an important role in wear particle-induced osteolysis. Therefore, in this study, we used adenovirus-mediated small interfering RNA (siRNA) targeting TNF- $\alpha$ to suppress the TNF- $\alpha$ release from activated macrophages in response to titanium particles. Our results showed that recombinant adenovirus (Ad-TNF- $\alpha$-siRNA) suppressed the TNF- $\alpha$ release from activated macrophages in response to titanium particles, and reduced titanium particle-induced osteoclastogenesis and bone resorption in the presence of receptor activator of nuclear factor- $\kappa \mathrm{B}$ ligand (RANKL). In addition, the conditioned medium of macrophages challenged with titanium particles ( $\mathrm{Ti} \mathrm{CM}$ ) stimulated osteoprogenitor RANKL expression. The conditioned medium of macrophages challenged with titanium particles and Ad-TNF- $\alpha$-siRNA (Ti-Ad CM) reduced the mRNA expression in MC3T3-E1 cells compared to Ti CM. Based on these data, TNF- $\alpha$ strongly synergizes with RANKL to promote osteoclast differentiation. Furthermore, TNF- $\alpha$ promoted osteoclast differentiation by stimulating osteoprogenitor RANKL expression. Ad-TNF- $\alpha$-siRNA effectively suppressed osteoclast differentiation and bone resorption following exposure to titanium particles in the presence of RANKL. In addition, recombinant adenovirus (Ad-TNF- $\alpha$ siRNA) does not have a toxic effect on the murine macrophage cell line, RAW264.7. Consequently, it can be concluded that
\end{abstract}

Correspondence to: Dr Qunhua Jin, Ningxia Medical University Affiliated Hospital, Yinchuan, P.R. China

E-mail: jinqunhua@sina.com

Key words: tumor necrosis factor- $\alpha$, osteoclast, RAW264.7 macrophages, NFATc1, small interfering RNA, titanium particles, osteolysis, osteoclast recombinant adenovirus-mediated siRNA targeting TNF- $\alpha$ (Ad-TNF- $\alpha$-siRNA) may provide a novel therapeutic approach for the treatment of periprosthetic osteolysis.

\section{Introduction}

The development of artificial joints is a major accomplishment of orthopedic surgery, and joint replacement remains one of the most common and successful surgical procedures. Unfortunately, wear debris is formed at prosthetic joint articulations, modular interfaces, and non-articulating interfaces $(1,2)$, which is the main reason for prosthetic failure (3-5). Researchers further believe that the biological response to wear particles at the bone-implant interface is considered the main cause of aseptic loosening and osteolysis $(6,7)$.

During this pathological process, macrophages are activated to release pro-inflammatory mediators, including tumor necrosis factor- $\alpha$ (TNF- $\alpha$ ), and interleukin (IL)- 6 and IL-1 $\beta$ in vitro (8-10), which have also been shown to be present in periprosthetic soft tissue in vivo (11). The differentiation and activation of macrophages is further enhanced by circulating pro-inflammatory factors. These inflammatory factors induce local chronic inflammatory response with the activation and recruitment of osteoclasts to the bone-implant interface, leading to periprosthetic osteolysis and aseptic loosening.

Previously studies have suggested that TNF- $\alpha$ augments the osteoblast expression of receptor activation of nuclear factor (NF)- $\kappa \mathrm{B}$ ligand (RANKL) and macrophage colony-stimulating factor (M-CSF) $(12,13)$. M-CSF and RANKL have been identified as the 2 principal cytokines of osteoclast differentiation and activation (14-16). RANKL binds to its membrane-bound signaling receptor, RANK, and stimulates osteoclast differentiation and maturation $(17,18)$. Osteoprotegerin $(\mathrm{OPG})$ is a soluble decoy receptor for RANKL and inhibits its effects by binding to RANKL (19).

TNF- $\alpha$ blocks the Wnt signaling pathway; the Wnt signaling pathway positively regulates the osteoblast expression of OPG and the inhibition of this pathway diminishes the expression of OPG (20-22). It can be hypothesized that TNF- $\alpha$ inhibits the expression of OPG. RANKL and OPG stimulate and inhibit, respectively, osteoclast differentiation. In this respect, the RANKL/OPG ratio is the principal axis that regulates the 
osteoclastogenic event, and this ratio is significantly higher in severe osteolysis (23). Thus, reducing the RANKL/OPG ratio would inhibit the formation of osteoclasts (24). The OPG/ RANKL/RANK signaling pathway is the most important pathway affecting osteoclast differentiation and functional regulation. OPG, M-CSF and RANKL are expressed by stromal cells/osteoblasts. Moreover, in vitro experiments have shown that TNF- $\alpha$ promotes the expression of RANK and $\mathrm{M}-\mathrm{CSF}$ on the cell membrane of osteoclast precursor cells; as a result, the RANKL and M-CSF signal is amplified $(25,26)$.

The binding of RANKL to RANK prompts the induction of several intracellular pathways by this receptor, leading to the activation of key transcription factors, most notably $\mathrm{NF}-\kappa \mathrm{B}$. It has been reported that the NF- $\mathrm{B}$ family of transcription factors is crucial to pathologic responses and is essential for osteoclast differentiation $(27,28)$. A number of studies have shown that the role of TNF- $\alpha$ can be observed from the NF- $\kappa \mathrm{B}, \mathrm{c}-\mathrm{Fos}$ and nuclear factor of activated T-cells, cytoplasmic, calcineurin-dependent 1 (NFATc1) activity change in osteoclast precursor cells, inducing the differentiation of osteoclast precursor cells independent of RANKL/ RANK signaling (29-32). These studies reported that RANKL and TNF- $\alpha$ activate NF- $\kappa$ B, c-Fos and NFATc1 in a similar manner $(29,31)$; NF- $\kappa \mathrm{B}, \mathrm{c}-\mathrm{Fos}$ and NFATc1 are essential for the promotion of osteoclast differentiation. In addition, it has been reported that TNF- $\alpha$ stimulates osteoclast differentiation through a mechanism independent of the osteoclast differentiation factor (ODF)/RANKL-RANK system (33). TNF- $\alpha$ only enhances the osteoblast expression of RANKL to promote osteoclast differentiation; however, RANKL also independently promotes the differentiation of osteoclasts.

These cellular mediators from macrophages may act in an autocrine and paracrine fashion to induce an imbalance between bone formation and resorption either by enhancing the osteoclastic lineage or by acting on stromal or osteoblastic cells, leading to the loss of bone stock (34). It has previously been reported that TNF- $\alpha$ and IL-1 $\beta$ suppress osteoblast differentiation $(35,36)$. It has also been reported that $\mathrm{c}$-Src and IL-6 inhibit osteoblast differentiation (18) and that TNF- $\alpha$ secreted from macrophages activated by titanium particles suppresses early and late differentiation markers of osteoprogenitor cells (20). TNF- $\alpha$ increases the expression of IL-6 through the activation of $\mathrm{NF}-\kappa \mathrm{B}$ in osteoblast-like cells (37), and earlier reports have shown that TNF- $\alpha$ mobilizes and activates c-Src $(38,39)$. It can be hypothesized that TNF- $\alpha$ directly controls osteoblast function in addition to the induction of osteoclast differentiation, leading to increased bone resorption (40).

The formation of the periprosthetic bone bed is dependent on the balance of bone resorption and bone formation. TNF- $\alpha$, IL- 6 and IL-1 $\beta$ promote bone loss and inhibit bone formation, and the reduced bone formation also contributes to periprosthetic osteolysis.

Based on these views, it can be concluded that reducing the expression of TNF- $\alpha$ may provide a promising therapeutic strategy for the treatment of periprosthetic osteolysis. Therefore, in this study, we used adenovirus carrying small interfering RNA (siRNA) targeting TNF- $\alpha$ (Ad-TNF- $\alpha$ siRNA) to downregulate TNF- $\alpha$ expression. We examined whether the constructed recombinant adenovirus (Ad-TNF- $\alpha$ -
siRNA) can effectively suppress the TNF- $\alpha$ release from activated mocrophages in response to titanium particles. We also observed the inhibitory effects of Ad-TNF- $\alpha$-siRNA on titanium particle-induced osteoclast formation and bone resorption in the presence of RANKL, and investigated the effect of the conditioned medium of macrophages challenged with titanium particles (Ti CM) and Ad-TNF- $\alpha$-siRNA (Ti-Ad CM) on osteoblasts (MC3T3-E1).

\section{Materials and methods}

Preparation of titanium particles. Commercially pure titanium particles were obtained from Zimmer Company (Warsaw, IN, USA). The majority of the titanium particles (90\%) were $<10 \mathrm{~mm}$ in diameter. Titanuim particles were prepared as previously described (41). The particles were sterilized by baking at $180^{\circ} \mathrm{C}$ for $6 \mathrm{~h}$, followed by treatment with $70 \%$ ethanol for $48 \mathrm{~h}$ to remove endotoxin. The particle endotoxin level was $>0.1 \mathrm{EU} / \mathrm{ml}$, as determined using a commercial detection kit (E-Toxate; Sigma, St. Louis, MO, USA). Titanium particles were sonicated and vortexed prior to treatment.

The concentration of particles that was used for incubation was $0.1 \mathrm{mg} / \mathrm{ml}$, which is similar to the concentration of wear particles that were retrieved from the periprosthetic tissues $(42,43)$.

Construction of adenovirus expressing TNF- $\alpha$-siRNA. siRNA targeting the TNF- $\alpha$ coding region (sense, 5'-GGUUGCCUC UGUCUCAGAATT-3' and antisense, 5'-UUCUGAGACAGA GGCAACCTG-3') were inserted into the KpnI and SpeI sites in the pSilencer 2.1-hU6 vector to generate vectors expressing TNF- $\alpha$-siRNA, amplified with PCR and cloned into the pGEMT vectors. TNF- $\alpha$-siRNA were then cut from the pGEMT vectors with KpnI and SpeI, and cloned into the same restriction sites of pAd5 E1-MCS-CMVeGFP. The plasmid was amplified by transformation into DH5 $\alpha$ cells and positive clones were selected and confirmed by the DNA Miniprep kit and KpnI digestion. The resultant plasmid, pAd5E1-hU6-TNF $\alpha$-siRNA-CMVeGFP, was linearized with $\mathrm{PacI}$ digestion and subsequently co-transformed into HEK293 cells with E3 deleted Ad backbone.

Infection of RAW264.7with Ad-TNF-a-siRNA.RAW264.7 cells were plated in 6 -well plates at a density of $4 \times 10^{5}$ cells/well. After $24 \mathrm{~h}$, the infection of RAW264.7 cells was carried out. The medium was removed and the cells were incubated with titanium particles and Ad-TNF- $\alpha$-siRNA [multiplicity of infection (MOI) of 50]. After $48 \mathrm{~h}$, total mRNA and protein were extracted to detect the expression of TNF- $\alpha$ by real-time RT-PCR and western blot analysis.

Cell culture. RAW264.7 murine macrophage/monocyte cells (BH-AC71; ATCC) were maintained at $37^{\circ} \mathrm{C}$ and $5 \% \mathrm{CO}_{2}$ in Dulbecco's modified Eagle's medium (DMEM; Sigma) containing 10\% FBS (HyClone, Logan, UT, USA), $100 \mathrm{U} / \mathrm{ml}$ penicillin, and $100 \mathrm{U} / \mathrm{ml}$ streptomycin at $37^{\circ} \mathrm{C}$ and $5 \% \mathrm{CO}_{2}$. MC3T3-E1 murine osteoblastic cells (ATCC) were cultured in $\alpha$-minimum essential medium ( $\alpha$-MEM; Sigma) supplemented with containing $10 \% \mathrm{FBS}, 100 \mathrm{U} / \mathrm{ml}$ penicillin and $100 \mathrm{U} / \mathrm{ml}$ streptomycin at $37^{\circ} \mathrm{C}$ and $5 \% \mathrm{CO}_{2}$. 
Table I. Primers for real-time RT-PCR.

\begin{tabular}{lll}
\hline Target & \multicolumn{1}{c}{ Forward primer $\left(5^{\prime} \rightarrow 3^{\prime}\right)$} & \multicolumn{1}{c}{ Reverse primer $\left(3^{\prime} \rightarrow 5^{\prime}\right)$} \\
\hline TNF- $\alpha$ & TCTTCTCATTCCTGCTTGTG & ACTTGGTGGTTTGCTACG \\
IL-6 & TCCATCCAGTTGCCTTCTTG & TTTCTCATTTCACGATTTCCC \\
IL-1 $\beta$ & ATCTCGCAGCAGCACATC & CAGCAGGTTATCATCATCATCC \\
TRAP & GCAGCCAAGGAGGACTAC & CCCACTCAGCACATAGCC \\
NFATc1 & TCTTCCGAGTTCACATCC & ACAGCACCATCTTCTTCC \\
GADPH & TCAACGGCACAGTCAAGG & ACTCCACGACATACTCAGC \\
M-CSF & TATTGCGACACCGAATCC & CTTGCTGATCCTCCTTCC \\
RANKL & CAGGAGGATGAAACAAGCC & GCAGCATTGATGGTGAGG \\
OPG & GTGTGAGTGTGAGGAAGG & TTTATACAGGGTGCTTTCG
\end{tabular}

TNF- $\alpha$, tumor necrosis factor- $\alpha$; IL, interleukin; TRAP, tartrate-resistant acid phosphatase; NFATc1, nuclear factor of activated T-cells, cytoplasmic, calcineurin-dependent 1 ; M-CSF, macrophage colony-stimulating factor; RANKL, receptor activator of nuclear factor- $\kappa \mathrm{B}$ ligand; OPG, osteoprotegerin.

Collection of conditioned medium. RAW264.7 cells were plated at a density of $1.0 \times 10^{5}$ cells/24-well plates in complete DMEM. After $24 \mathrm{~h}$ of attachment, the cells were washed with PBS and stabilized with serum-free DMEM for $1 \mathrm{~h}$. The cells were then cultured with titanium particles $(0.1 \mathrm{mg} / \mathrm{ml})$ or titanium particles and Ad-TNF- $\alpha$-siRNA. After $24 \mathrm{~h}$ of incubation with control (Cont CM), titanium-conditioned medium(Ti CM), or titanium with Ad-TNF- $\alpha$-siRNA conditioned medium (Ti-Ad CM), the cells were collected, centrifuged to remove the cell debris if any, and stocked at $-20^{\circ} \mathrm{C}$ until use. The conditioned medium was prepared as previously described (20).

RNA isolation andreal-time RT-PCR. Total RNA was extracted using TRIzol (Invitrogen) according to the manufacturer's instructions. The 260/280 absorbance ratio was measured for verification of the RNA purity (NanoDrop). The firststrand cDNA was synthesized with $2 \mu \mathrm{g}$ of total RNA using the RevertAid First Strand cDNA Synthesis kit (Fermentas), and one tenth of the cDNA was used for each PCR mixture containing Express SYBR-Green PCR Supermix (Fermentas). The reaction was subjected to a 40-cycle amplification at $95^{\circ} \mathrm{C}$ for $30 \mathrm{sec}$, at $95^{\circ} \mathrm{C}$ for $5 \mathrm{sec}$ and at $60^{\circ} \mathrm{C}$ for $30 \mathrm{sec}$. Relative mRNA expression of selected genes was normalized to GAPDH and quantified using the $\Delta \Delta C T$ method. The sequences of the PCR primers are listed in Table I.

Protein isolation and western blot analysis. Cells were lysed in RIPA buffer (20 mM Tris-HCl, pH 7.5, $200 \mathrm{mM} \mathrm{NaCl}, 1 \%$ Triton X-100 and $1 \mathrm{mM}$ dithiothreitol) containing protease inhibitor cocktail (Roche, Indianapolis, IN). The protein concentration was measured with a protein assay kit (BCA) following the manufacturer's instructions. Total protein was subjected to SDS-polyacrylamide gel electrophoresis and transferred onto PVDF membranes. The blot was probed with primary antibodies; anti-TNF- $\alpha$, NFATc1 (both from Cell Signaling Technology, Inc., Danvers, MA, USA) and anti-bone morphogenetic protein (BMP)-2 (Abcam, Cambridge, MA, USA). Anti- $\beta$-actin (CWBiotech, Beijing, China) was used as a loading control. Subsequently, the blots were washed in TBST (10 mM Tris- $\mathrm{HCl}, 50 \mathrm{mM} \mathrm{NaCl}$ and $0.25 \%$ Tween-20) and incubated with secondary antibody. The presence of target proteins was detected using enhanced Chemiluminescence reagents (Millipore Corp., Billerica, MA, USA).

Cell viability: 3-(4,5-dimethylthiazol-2-yl)-2,5-diphenyl tetrazolium bromide (MTT) assay. The effect of recombinant adenovirus and titanium particles on RAW264.7 cell viability was examined using MTT assay. RAW264.7 cells ( $2 \times 10^{4}$ cells/ well) were cultured in RANKL and titanium particles containing DMEM with Ad-TNF- $\alpha$-siRNA for 24,48 and $72 \mathrm{~h}$, and then incubated with $0.5 \mathrm{mg} / \mathrm{ml}$ of MTT at $37^{\circ} \mathrm{C}$ for $4 \mathrm{~h}$. Following the removal of the supernatant, the insoluble formazan crystal was dissolved in $200 \mathrm{ml}$ of dimethyl sulfoxide (DMSO) and absorbance was measured using a $490 \mathrm{~nm}$ wavelength Synergy microplate reader (BioTek Instruments).

Tartrate-resistant acid phosphatase (TRAP). RAW264.7 cells were plated at a density of $1 \times 10^{4}$ cells/96-well. After $24 \mathrm{~h}$ of attachment, the cells were cultured in the presence of soluble RANKL (50 ng/ml) and titanium particles $(100 \mu \mathrm{g} / \mathrm{ml})$ with or without Ad-TNF- $\alpha$-siRNA (MOI of 50) After 5 days, RAW264.7 cells with different treatments were fixed and stained for TRAP expression according to the manufacturer's instructions (Sigma). The nuclei were counterstained with acid hematoxylin solution. The TRAP-positive cells with $\geq 3$ nuclei were counted as osteoclasts (44).

Resorption pit assay for osteoclasts. RAW264.7 cells were plated at a density of $2 \times 10^{4}$ cells/24-well plates (Corning Inc., Corning, NY, USA). After $24 \mathrm{~h}$ of attachment, the cells were cultured in the presence of soluble RANKL (50 ng/ml) and titanium particles $(100 \mu \mathrm{g} / \mathrm{ml})$ with or without Ad-TNF- $\alpha$-siRNA (MOI of 50). After 10 days, to analyze the surface for pit formation, the medium was aspirated from the wells, and $100 \mu \mathrm{l}$ of $10 \%$ bleach solution were added. Cells were incubated with the bleach solution for $5 \mathrm{~min}$ at room temperature. The wells were washed twice with distilled water and allowed to dry at room temperature for 3 to $5 \mathrm{~h}$. Individual pits or multiple pit clusters were observed using a microscope at $\times 10$ magnification (Leica). We selected 4 images by the sum of absorption area in 


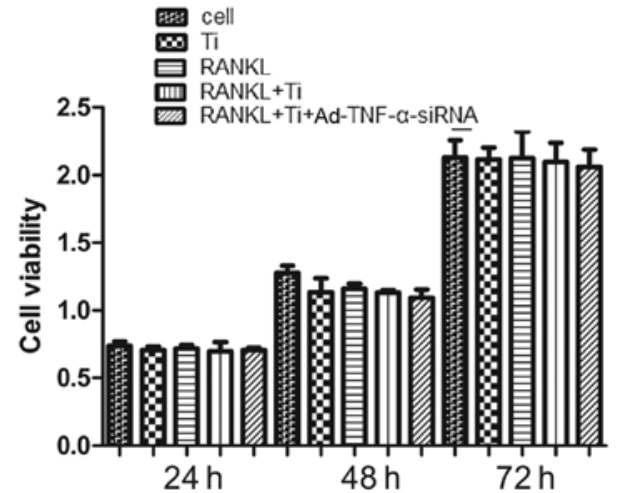

Figure 1. RAW264.7 cells were treated with titanium (Ti) particles and/ or RANKL in the presence or absence of Ad-TNF- $\alpha$-siRNA for 24-72 $\mathrm{h}$ as indicated. The cellular activity was then estimated by MTT assay. Data are expressed as the means $\pm \mathrm{SD}$.

each well for statistical analysis $(n=3)$. Bone absorption area was measured using image-analysis software (IPP6.0).

ELISA. RAW264.7 cells were incubated with titanium particles $(100 \mathrm{ng} / \mathrm{ml})$ for $24 \mathrm{~h}$. Ti CM was collected to determine the concentration of TNF- $\alpha$. Mouse TNF- $\alpha$ and the MBP-2 ELISA kit (Ameko) were used for a quantitative measurement according to the manufacturer's recommendations.

Statistical analysis. Data are expressed as the means \pm SE of $\geq 3$ determinations. Differences between groups were analyzed using analysis of variance (ANOVA). A P-value $<0.05$ was considered to indicate a statistically significant difference. Statistical analyses were performed using SPSS version 17.0 software.

\section{Results}

Effects of recombinant adenovirus (Ad-TNF- $\alpha$-siRNA) and titanium particles on cell viability. Compared to the controls, neither titanium particles nor a combination of titanium particles and Ad-TNF- $\alpha$-siRNA (MOI of 50) affected the viability of RAW264.7 cells (Fig. 1). These results suggest that both Ad-TNF- $\alpha$-siRNA (MOI of 50) and titanium particles are not toxic to RAW264.7 cells.

Suppressive effects of Ad-TNF- $\alpha$-siRNA on titanium particleinduced inflammatory factor. We investigated the effect of the downregulation of the mRNA expression of TNF- $\alpha$ by Ad-TNF- $\alpha$-siRNA from activated mocrophages in response to titanium particles using comparison tests with different MOIs (refers to virus particles added/cell). Our results showed that the mRNA expression of TNF- $\alpha$ was significantly reduced at a MOI of 50 after $48 \mathrm{~h}$ (Fig. 2A). The same result was observed for the TNF- $\alpha$ protein levels by western blot analysis after $48 \mathrm{~h}$ (Fig. 2B).

We also detected the expression of the inflammatory factors, IL-1 $\beta$ and IL-6. The results showed that the downregulation of TNF- $\alpha$ mRNA reduced the mRNA expression of inflammatory cytokines, such as IL-6 (Fig. 2C) and IL-1 $\beta$ (Fig. 2D). These results suggest that TNF- $\alpha$ promotes the mRNA expression of IL-6 and IL-1 $\beta$.
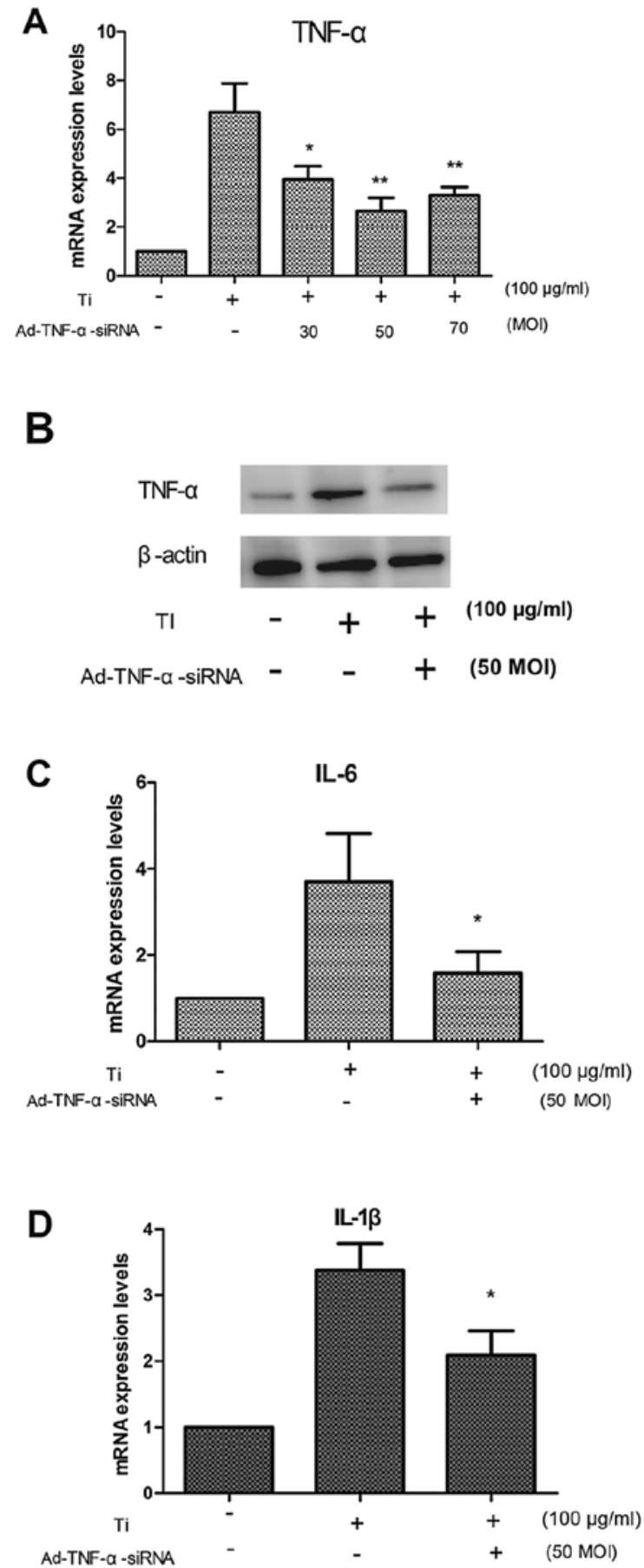

Figure 2. The expression of titanium particle-induced inflammatory factors was inhibited by Ad-TNF- $\alpha$-siRNA at various multiplicities of infection (MOIs) in RAW264.7 murine macrophage-like cells. (A) RAW264.7 cells were plated in 6 -well plates at a density of $4 \times 10^{5}$ cells/well. After $48 \mathrm{~h}$, total mRNA was extracted for gene expression by real-time PCR; the mRNA expression of TNF- $\alpha$ was significntly reduced by Ad-TNF- $\alpha$-siRNA at a MOI of 50 . ${ }^{*}$ Compared to culture with titanium (Ti) particles only. (B) The same result was observed for the TNF- $\alpha$ protein levels, as shown by western blot analysis after $48 \mathrm{~h}$. Ad-TNF- $\alpha$-siRNA at a MOI of 50 significantly reduced the mRNA expression of (C) IL-6 and (D) IL-1 $\beta$. Data are presented as the means \pm SD. Similar results were obtained in 3 independent experiments. ${ }^{*} \mathrm{P}<0.05$ and $^{* *} \mathrm{P}<0.01$.

Ad-TNF- $\alpha$-siRNA reduces titanium particle-induced osteoclastogenesis and bone resorption. TRAP is a marker that is widely used to identify osteoclasts. We examined the mRNA expression of TRAP in RAW264.7 cells cultured in the pres- 

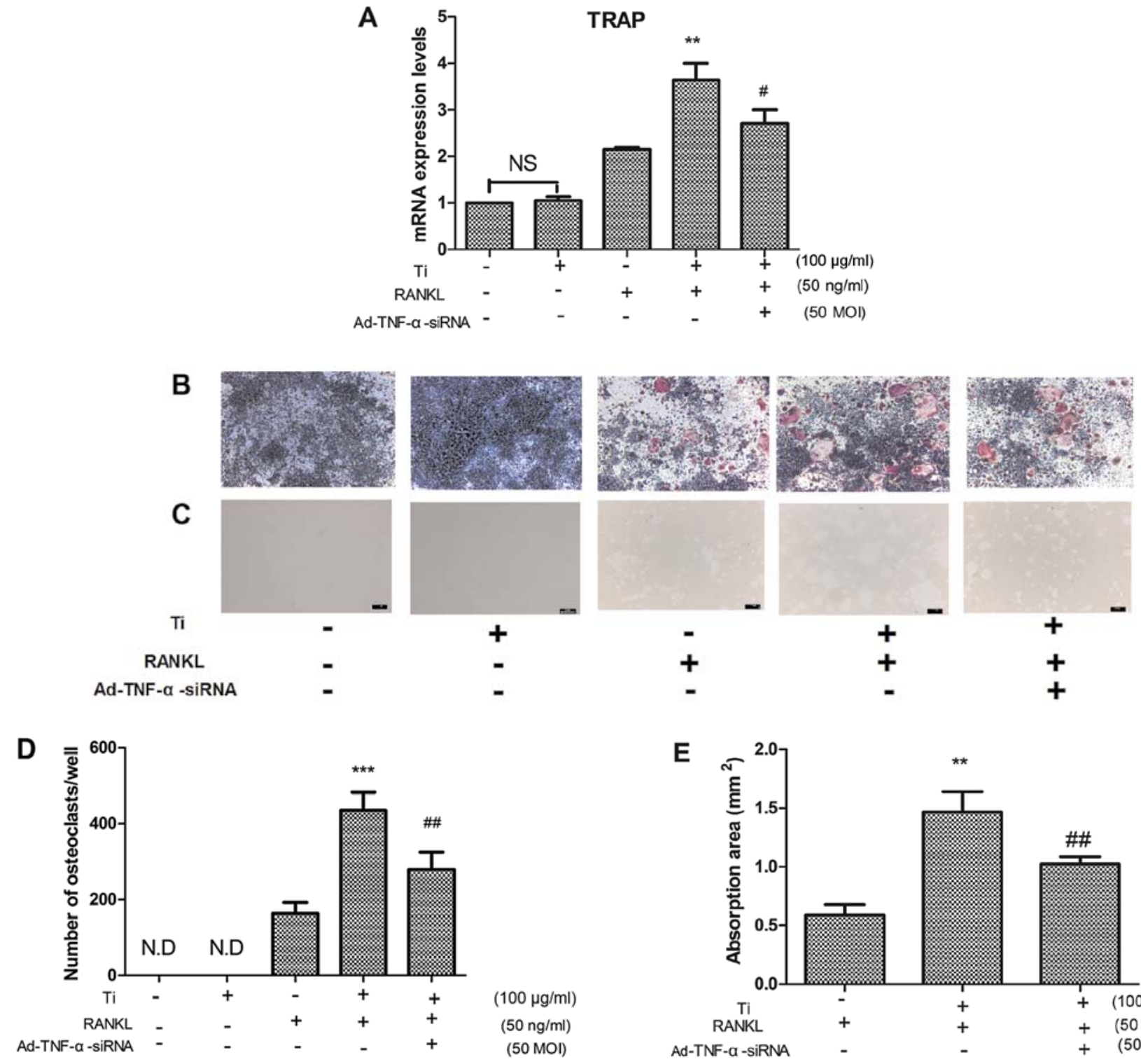

$(50 \mathrm{MOI})$

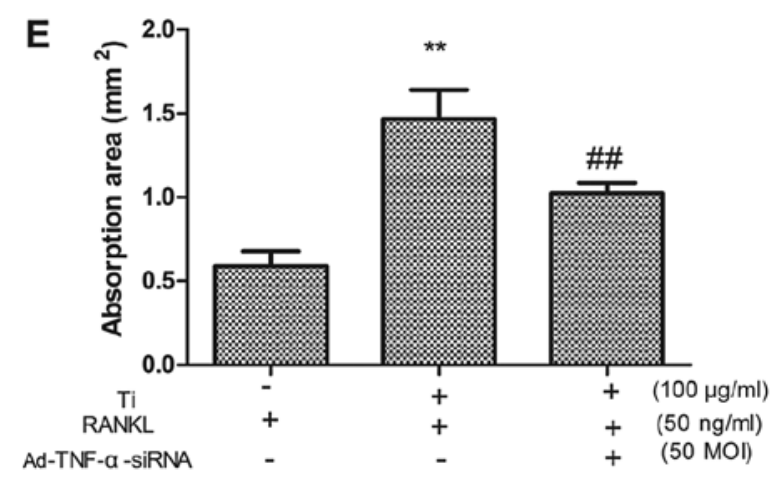

Figure 3. Ad-TNF- $\alpha$-siRNA reduced the titanium particle-induced osteoclastogenesis and bone resorption. (A) Real-time PCR showed that RANKL was essential for the expression of TRAP mRNA. (B) Osteoclast differentiation of RAW264.7 cells was identified by TRAP staining. TRAP ${ }^{+}$multinucleated cells were only observed in the cells cultured with RANKL, and titanium (Ti) particles increased the number of RAW264.7 cells differentiating into osteoclasts in the presence of RANKL. The downregulation TNF- $\alpha$ by Ad-TNF- $\alpha$-siRNA effectively reduced osteoclast formation. (C and E) The resorption pits were examined using a microscope at x10 magnification (Leica). The measurements demonstrated that the area of the resorption pits was significantly increased on the osteoclasts in culture plates cultured in the presence of RANKL and titanium particles compared to the osteoclasts in the culture plates cultured with RANKL alone. The resorption area was significantly decreased on the osteoclaste culture plates after the addition of Ad-TNF- $\alpha$-siRNA. (D) There were no osteoclasts in the culture with titanium particles only. Osteoclasts were present in the RAW264.7 cells cultured with RANKL. A significant increase in the number of osteoclasts was observed in the cells cultured in the presence of titanium particles and RANKL compared to the RAW264.7 cells cultured with RANKL alone. Ad-TNF- $\alpha$-siRNA effectively reduced osteoclastogenesis in the cells cultured with RANKL and titanium particles. The quantitative data were expressed as the means \pm SD. ${ }^{* *} \mathrm{P}<0.01$, compared to the cells cultured with RANKL alone. ${ }^{* * *} \mathrm{P}<0.001$, compared to the cells cultured with RANKL alone; ${ }^{\#} \mathrm{P}<0.05$, compared to the cells cultured with RANKL and Ti particles. ${ }^{\# \prime} \mathrm{P}<0.01$. ND, not detected.

ence of RANKL and/or titanium particles for 4 days. Our data showed that the mRNA expression of TRAP was significantly higher in the cells cultured with titanium particles than in those cultured without titanium particles in the presence of RANKL (Fig. 3A). The downregulation TNF- $\alpha$ by Ad-TNF- $\alpha$-siRNA reduced the mRNA expression of TRAP (Fig. 3A). Titanium particles did not stimulate the mRNA expression of TRAP in RAW264.7 cells in the absence of RANKL. The number of $\mathrm{TRAP}^{+}$multinucleated cells was also significantly higher in the cells cultured with titanium particles than in those cultured without titanium particles in the presence of RANKL
(Fig. 3B and D). Osteoclastogenesis did not occur in the cells cultured without RANKL. These results suggest that TNF- $\alpha$ stimulates osteoclastogenesis only in the presence of RANKL.

We further investigated osteoclast function induced by titanium particles and RANKL with or without Ad-TNF- $\alpha$ siRNA. We examined resorption pits on osteoclast culture plates. The results showed that the area of the resorption pits was significantly greater on the osteoclast culture plates cultured with titanium particles than on those cultured without particles in the presence of RANKL (Fig. 3C and E). The downregulation of TNF- $\alpha$ by Ad-TNF- $\alpha$-siRNA significantly 
A

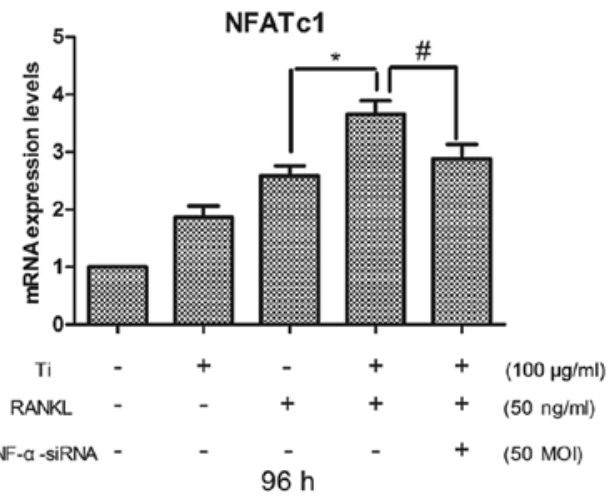

C

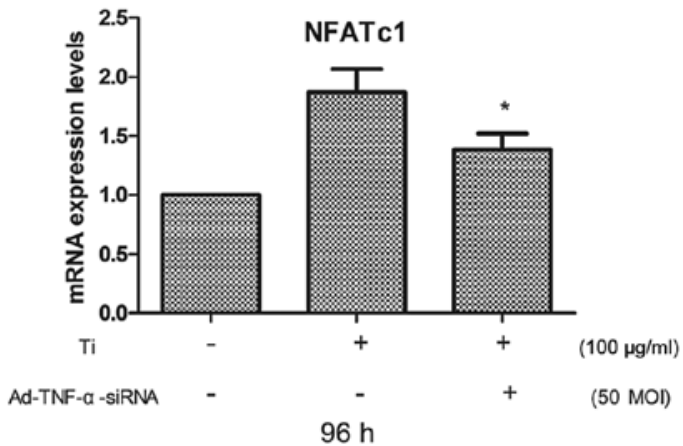

B

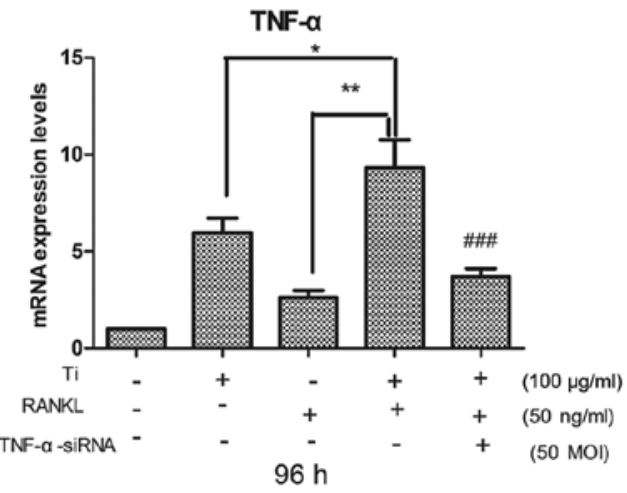

D

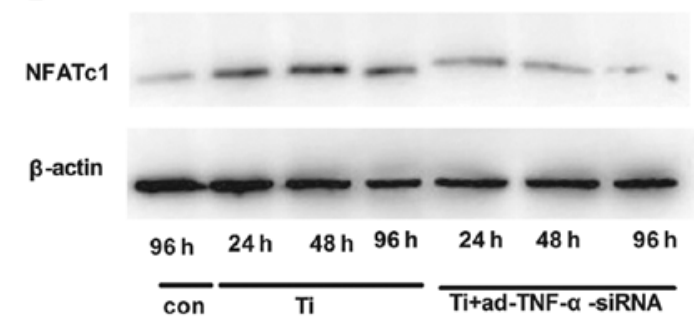

Figure 4. Effect of titanium (Ti) particles and RANKL on NFATc1. (A) NFATc1 activation was observed in the cells cultured with titanium particles and/or RANKL. The mRNA expression of NFATc1 was decreased by Ad-TNF- $\alpha$-siRNA in the cells cultured with titanium particles and RANKL. ${ }^{* *} \mathrm{P}<0.01$, compared to the cells cultured with RANKL alone; ${ }^{\text {P }}<<0.05$, compared to the cells cultured with titanium particles and RANKL. (B) We further detected TNF- $\alpha$ expression. RANKL increased the mRNA TNF- $\alpha$ expression. ${ }^{* *} \mathrm{P}<0.01$, compared to the cells cultured with RANKL alone; ${ }^{\# \#} \mathrm{P}<0.01$, compared to the cells cultured with titanium particles and RANKL. (C) The expression NFATc1 mRNA was decreased by Ad-TNF- $\alpha$-siRNA in the cells cultured with titanium particles alone. ${ }^{*} \mathrm{P}<0.05$, compared to cells cultured with titanium particles alone. (D) Western blot analysis revealed that NFATc1 expression was activated by titanium particles alone, and under this condition the downregulation of TNF- $\alpha$ by Ad-TNF- $\alpha$-siRNA reduced the NFATc1 expression. The quantitative data were expressed as the means \pm SD.

reduced the area of the resorption pits on the osteoclast culture plates compared to that on the plates cultured with titanium particles and RANKL (Fig. 3C and E). These results suggest that TNF- $\alpha$ may exert a strong synergistic effect with RANKL, increasing local bone resorption in vivo.

NFATc1 plays a crucial role in osteoclastogenesis $(45,46)$. Real-time PCR demonstrated that in the presence of RANKL, the mRNA expression of NFATc1 in the RAW264.7 cells cultured with titanium particles was greater than in the cells cultured without titanium particles (Fig. 4A). The downregulation of TNF- $\alpha$ by Ad-TNF- $\alpha$-siRNA in the cells cultured with titanium particles and RANKL reduced the expression of NFATc1 compared to that in cells cultured without Ad-TNF- $\alpha$ siRNA (Fig. 4A). These results showed that TNF- $\alpha$ expression was induced in the cells cultured with RANKL (Fig. 4B). Real-time RT-PCR revealed that the downregulation of TNF- $\alpha$ by Ad-TNF- $\alpha$-siRNA reduced NFATc1 expression in the cells cultured with titanium particles and RANKL (Fig. 4A). These results suggest that NFATc1 is activated by TNF- $\alpha$.

We further determined NFATc1 expression in RAW264.7 cells cultured with titanium particles in the absence of RANKL. We examined NFATc1 expression by real-time PCR and western blot analysis. The results showed that the titanium particles activated the expression of NFATc1, and that the downregulation of TNF- $\alpha$ by Ad-TNF- $\alpha$-siRNA reduced the expression of NFATc1 in the cells cultured without RANKL
(Fig. 4C). Western blot analysis revealed that the downregulation of TNF- $\alpha$ reduced NFATc1 protein expression in the cells in a time-dependent manner (Fig. 4D). These results demonstrated that TNF- $\alpha$ activated NFATc1 expression, and suggest that the synergistic effect of TNF- $\alpha$ with RANKL increases local osteoclastogenesis and bone resorption; this synergistic effect activates the expression of NFATc1. NFATc1 is essential to promote osteoclast differentiation (47).

Effects of conditioned medium on MC3T3-E1 mouse osteoblastic cell line. RANKL has been identified as the principal cytokine of osteoclast differentiation and activation. RANKL is synthesized by stromal cells/osteoblasts. We examined the effect of Ti CM on RANKL and M-CSF expression in MC3T3-E1 cells. The results showed that Ti CM significantly increased the mRNA expression of RANKL in MC3T3-E1 cells (Fig. 5A), and Ti CM had absolutely no effect on the mRNA expression of M-CSF in the MC3T3-E1 cells. OPG expression was not detected by real-time RT-PCR under our culture conditions. Ti-Ad CM significantly reduced the mRNA expression of RANKL (Fig. 5A). In addition, RANKL stimulated RAW264.7 mouse macrophages cell differentiation into osteoclasts on its own in a dose-dependent manner in vitro (Fig. 7). Thus, these results suggest that TNF- $\alpha$ can indirectly promote osteoclast differentiation by increasing RANKL expression in MC3T3-E1 cells. Ad-TNF- $\alpha$-siRNA significantly reduced the expression of RANKL. 

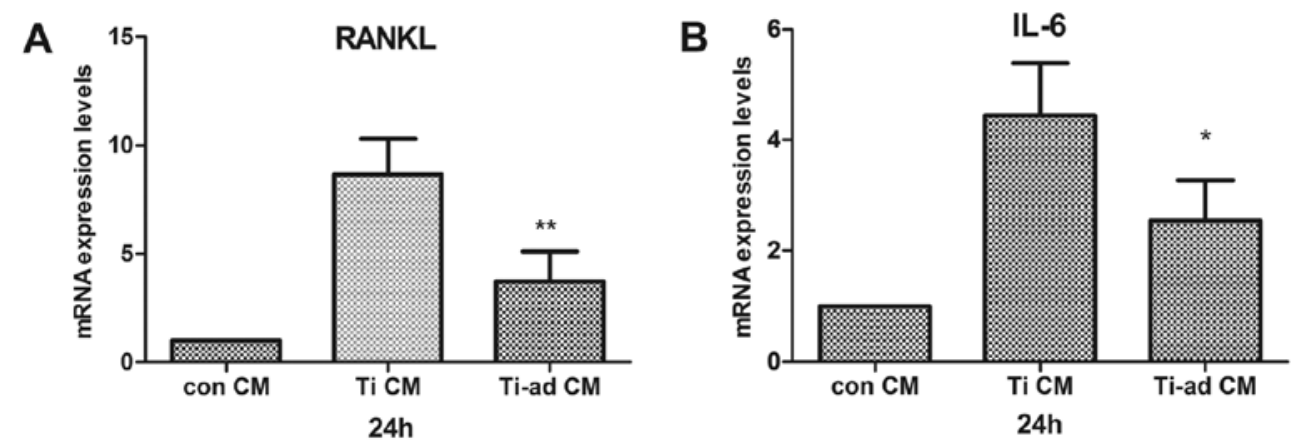

Figure 5. Effect of conditioned medium (Ti CM and Ti-Ad CM) on MC3T3-E1 mouse osteoblastic cell line. (A and B) The mouse osteoblastic cells were plated in 24-well plates at a density of $1 \times 10^{5}$ cells/well in culture with Ti CM or Ti-Ad CM. After $24 \mathrm{~h}$, real-time PCR showed that the mRNA expression of RANKL and IL-6 was significantly increased in the cells cultured with Ti CM; and under this condition the mRNA expression of RANKL and IL-6 was significantly reduced in the cells culture with Ti-Ad CM compared to the cells cultured with Ti CM. The quantitative data are expressed as the means $\pm \mathrm{SD}$. ${ }^{*} \mathrm{P}<0.05$, compared to the cells cultured with Ti $\mathrm{CM} ;{ }^{* *} \mathrm{P}<0.01$, compared to the cells cultured with Ti CM.

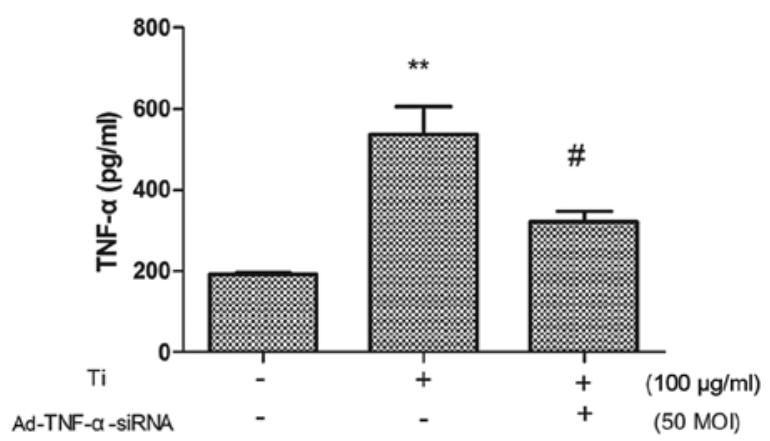

Figure 6. Detection of the release of TNF- $\alpha$ from the activated RAW264.7 cells in reaction to titanium (Ti) particles. TNF- $\alpha$ expression was significantly increased in the cells cultured with titanium particles, and TNF- $\alpha$ expression was significantly reduced in the cells cultured with titanium particles and Ad-TNF- $\alpha$-siRNA. The quantitative data are expressed as the means \pm SD. ${ }^{* *} \mathrm{P}<0.01$, compared to the controls; ${ }^{*} \mathrm{P}<0.05$, compared to the cells cultured with titanium particles alone.

We further examined IL-6 expression in MC3T3-E1 cells cultured with Ti CM or Ti-Ad CM. Our results showed that IL-6 expression was increased in the MC3T3-E1 cells cultured with $\mathrm{Ti} \mathrm{CM}$, and was reduced in the cells cultured with Ti-Ad CM (Fig. 5B). These results suggest that TNF- $\alpha$ promotes IL-6 expression in MC3T3-E1 cells.

\section{Discussion}

The present study describes a novel approach for inflammatory reduction in activated macrophages in response to titanium particles by siRNA-mediated TNF- $\alpha$ silencing in the RAW264.7 mouse macrophage cell line. Recombinant adenovirus (Ad-TNF- $\alpha$-siRNA) significantly inhibited the TNF- $\alpha$ release from activated macrophages in response to particle debris. We detected TNF- $\alpha$ expression in macrophages activated by titanium particles by real-time PCR and western blot analysis (Fig. 2A and B). The downregulation of TNF- $\alpha$ by Ad-TNF$\alpha$-siRNA also reduced the gene expression of inflammatory cytokines, such as IL-1 $\beta$ (Fig. 2D) and IL-6 (Fig. 2C); these inflammatory factors play a critical role in osteolysis (48). Our data suggest that titanium particles stimulate RAW264.7 mouse macrophage cells to secrete pro-inflammatory cytokines, such

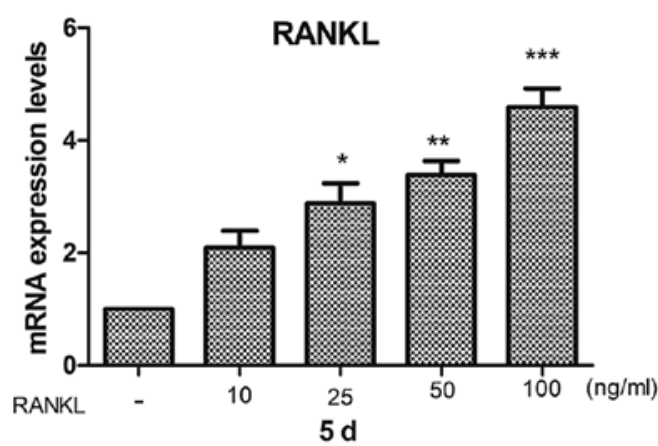

Figure 7. RANKL stimulates RAW264.7 mouse macrophages cell differentiation into osteoclasts on its own in a dose-dependent manner in vitro. The quantitative data are expressed as the means $\pm \mathrm{SD}$. ${ }^{*} \mathrm{P}<0.05$, compared to the cells cultured with RANKL $(10 \mathrm{ng} / \mathrm{ml}) ;{ }^{* *} \mathrm{P}<0.01$, compared to the cells cultured with RANKL $(10 \mathrm{ng} / \mathrm{ml}) ;{ }^{* * *} \mathrm{P}<0.001$, compared to the cells cultured with RANKL (10 ng/ml).

as TNF- $\alpha$, IL-1 $\beta$ and IL-6; these cytokines may not directly induce RAW264.7 mouse macrophage cells to differentiate into osteoclasts in the absence of RANKL, but these cytokines can activate NFATc1 mRNA expression in the absence of RANKL (Fig. 4A). A previous study indicated that inactivated NFATc1 can suppress titanium particle-induced osteoclast formation (10). NFATc1 is essential to promote osteoclast differentiation $(47,49)$. The downregulation of TNF- $\alpha$ by Ad-TNF- $\alpha$-siRNA reduced the expression of NFATc1 mRNA. Thus, we hypothesized that NFATC1 was activated by TNF- $\alpha$. This result is in agreement with that of a previous study (29). TNF- $\alpha$ cannot promote the formation of osteoclasts in the absence of RANKL, but TNF- $\alpha$ promotes the formation of osteoclasts in the presence of RANKL, in accordance with previous studies $(50,51)$. RANKL stimulates osteoclast precursor differentiation into osteoclasts by activating c-Fos, NF- $\kappa B$ and NFATc1 $(29,47,51)$. TNF- $\alpha$ activates NF- $\kappa B$, c-Fos and NFATc1 in a similar manner (29). Despite activating similar signaling, TNF- $\alpha$ does not effectively induce osteoclast differentiation in the absence of RANKL (Fig. 3D). Thus, it can be hypothesized that NFATc1, TNF- $\alpha$, IL-1 $\beta$ and IL- 6 cannot activate the terminal differentiation of osteoclasts. TNF- $\alpha$ has already been proven to stimulate osteoclast differentiation in the presence of M-CSF. Therefore, we hypothesized that 
TNF- $\alpha$ cannot directly induce osteoclast differentiation, but indirectly induces osteoclast differentiation in the presence of RANKL and/or M-CSF. Thus, RANKL and M-CSF can activate the terminal differentiation of osteoclasts.

Titanium particles in conjunction with RANKL stimulate osteoclast formation and bone absorption; this effect is more evident in the presence of both titanium particles and RANKL, than with RANKL alone. The downregulation of TNF- $\alpha$ by Ad-TNF- $\alpha$-siRNA in activated macrophages in response to titanium particles reduced the formation of osteoclasts and bone absorption in the presence of RANKL and titanium particles compared with group cultured with titanium particles and RANKL without Ad-TNF- $\alpha$-siRNA (Fig. 3). Our results show that TNF- $\alpha$ cannot directly effectively promote osteoclast formation in the absence of RANKL, but TNF- $\alpha$ and RANKL have a synergistic effect, promoting osteoclast formation and bone absorption. At the same time, our results showed that the expression of NFATc1 in the presence of RANKL and titanium particles was significantly higher than in the presence of RANKL alone, and that the downregulation of TNF- $\alpha$ by recombinant adenovirus significantly reduced the expression of NFATc1. However, the above results confirmed that TNF- $\alpha$ slightly activated the expression of NFATc1; thus, we detected the expression of TNF- $\alpha$ in the titanium, RANKL and RANKL and titanium group. Our results confirmed that RANKL also stimulated the expression of TNF- $\alpha$. The increased expression of TNF- $\alpha$ increased the expression of NFATc1. Furthermore, it was confirmed that TNF- $\alpha$ promotes the expression of RANK on the cell membrane of osteoclast precursor cells; as a result, the RANKL signal is amplified, further activating NFATc1 expression. Thus, we hypothesized that the mechanism behind the synergistic promoting effect of TNF- $\alpha$ and RANKL on osteoclast formation and bone absorption may well be that TNF- $\alpha$ activates NFATc1 to facilitate osteoclast formation and bone absorption in the presence of RANKL. Recombinant adenovirus (Ad-TNF- $\alpha$-siRNA) effectively reduces osteoclasts formation and bone resorption.

RANKL and M-CSF are essential to promote the osteoclast differentiation factor, which is expressed in osteoblasts during each stage, and TNF- $\alpha$ augments the osteoblast expression of RANKLand M-CSF $(12,52,53)$.RANKL has beendemonstrated to not only deliver a final osteoclast differentiation signal, but to also activate osteoclasts and promote their survival (54-57).

Our results indicated that RANKL stimulated RAW264.7 mouse macrophages cell differentiation into osteoclasts on its own in a dose-dependent manner in vitro (Fig. 7). RANKL expression was increased in the conditioned medium collected from macrophages activated by Ti CM in vitro (Fig. 5A). Furthermore, the mRNA expression of RANKL was downregulated in the conditioned medium collected from macrophages activated by titanium particles and pre-treated with Ad-TNF- $\alpha$-siRNA (Ti-Ad CM) compared to that in conditioned medium of the cells from the Ti CM pre-treated group (Fig. 5A). Therefore, we speculated that TNF- $\alpha$ in the macrophages activated by titanium particles augments the osteoblast expression of RANKL. Taken together, these data suggest that TNF- $\alpha$ indirectly promotes osteoclast differentiation by increasing RANKL expression in MC3T3-E1 cells.

Bone remodeling is a physiological process that involves the resorption and synthesis of bone by osteoclasts and osteoblasts, respectively (59). During the pathological process, TNF- $\alpha$, IL-1 $\beta$ and IL-6 are overexpressed in macrophages stimulated by titanium particles (58). These inflammatory factors have been shown to suppress osteoblast differentiation $(35,36,60)$. It has been proven that $\mathrm{Ti} \mathrm{CM}$ reduces osteogenic parameters, such as alkaline phosphatase (ALP) activity and the expression of Runt-related transcription factor 2 (Runx2), and suppresses late differentiation markers of osteoprogenitor cells (20). TNF- $\alpha$, IL-1 $\beta$ and IL- 6 are overexpressed in macrophages activated by titanium particles, but only TNF- $\alpha$ mimicks the effects of Ti CM on the ALP activity of osteoprogenitor cells, compared to IL- $1 \beta$ and IL-6. IL-1 $\beta$ and IL-6 have no significant effect on ALP activity (20). Thus, it can be hypothesized that TNF- $\alpha$ suppresses osteoblast differentiation. This idea is consistent with previous studies $(36,61)$. Thus, Ad-TNF$\alpha$-siRNA can inhibit the suppressive effect of TNF- $\alpha$ on osteoblast differentiation.

A recent study illustrated that IL-6 impairs osteoblast maturation in immature osteoblasts in vitro and in vivo. By contrast, in mature osteoblasts, IL-6 is no longer able to impair osteoblast maturation (60). It has been reported that TNF- $\alpha$ increases the expression of IL-6 in osteoblast-like cells (37). This would aggravate the inhibitory effect on osteoblast differentiation. Nevertheless, the downregulation of TNF- $\alpha$ by Ad-TNF- $\alpha$-siRNA reduced the expression of IL-1 $\beta$ and IL-6 in macrophages activated by titanium particles (Fig. $2 \mathrm{C}$ and D). The expression of IL- 6 in the MC3T3-E1 cells cultured in conditioned medium challenged with titanium particles and Ad-TNF- $\alpha$-siRNA (Ti-Ad CM) was reduced compared with that in the cells in the Ti CM group (Fig. 5B). Thus, Ad-TNF- $\alpha-$ siRNA can inhibit the suppressive effect of IL-6 on osteoblast differentiation through the reduced exogenous and endogenous IL-6 expression during the pathological process of titanium particle induced-osteolysis.

Moreover, the Wnt and BMP pathways are regulated by several processes; TNF- $\alpha$ is able to hamper osteoblast differentiation process by annulling Wnt and BMP signaling (20). Wnt and BMP pathways tightly regulate osteoblast differentiation (62). Furthermore, during the differentiation process of osteoblasts, OPG expression is significantly downregulated in osteocytes by abolishing Wnt signaling (63), suggesting that the reduction in osteocytic OPG and the concomitant increase in the osteocytic RANKL/OPG ratio contribute to the increased number of osteoclasts and resorption. In fact, Wnt serves as an autocrine stimulator of OPG expression in osteoblasts, and Wnt signaling promotes bone formation by upregulating OPG and downregulating RANKL (64). This shows that TNF- $\alpha$ not only inhibits bone formation by annulling Wnt and BMP-2, but also promotes bone absorption through the upregulation the RANKL/OPG ratio.

TNF- $\alpha$ and IL- 6 suppressed osteoblast differentiation, which likely establishes a functional loop to maintain osteoblasts in a less mature status. A previous study suggested that the RANKL/OPG ratio is increased in immature osteoblasts and is reduced in mature osteoblasts (65). TNF- $\alpha$ and IL-6 suppress osteoblast differentiation, leading to an increase in the number of immature osteoblasts and the concomitant increase in the immature osteoblast RANKL/OPG ratio contributes to the increased number of osteoclasts and resorption, and reduced bone formation. 
Osteoclasts and osteoblasts contribute individually to bone remodeling, whereas their interactions control their cellular activities, as well as the intensity of bone remodeling. These interactions can be established either through a cell-cell contact, in which molecules of the integrin family may be involved, or by the release of many polypeptide factors and/or their soluble receptor chains. During the pathological process of titanium particle-induced osteolysis, TNF- $\alpha$ not only promotes osteoclast formation and bone resorption in the presence of RANKL, but also suppresses osteoblast differentiation and increases the RANKL/OPG ratio, leading to bone mass loss, and the reduced bone formation also contributes to periprosthetic bone tissue; as a result periprosthetic osteolysis and subsequent aseptic loosening are the most common causes of TJA failure.

Thus far, there is no effective treatment for aseptic joint loosening apart from reoperation; the reoperation of patients causes serious physical and psychological trauma and increases the economic burden; reoperation also increases the risk of subsequent multiple peri-operative complications (particularly in elderly patients). Therefore, the discovery of non-surgical methods to combat aseptic joint loosening is a hot research topic; however, no effective treatment has yet been discovered. Although the mechanism behind aseptic joint loosening is not clear, it involves the generation of wear debris particles which are phagocytosed by macrophages and other inflammatory cells, resulting in cellular activation and the release of pro-inflammatory mediators and cytokines, which cause periprosthetic osteolysis and subsequent aseptic loosening, the most common causes of TJA failure (8,66-69). Our results confirmed that TNF- $\alpha$ plays an important role in the particle-induced osteoclastogenic and osteolytic events. This view is also supported by previous studies using animal models, in vitro cell cultures and clinic trials (70-73). Although therapeutic agents against pro-inflammatory mediators, such as TNF have shown promise in animal models, no approved treatments are yet available to osteolysis patients. There are concerns as to the side-effects of pharmaceutical drugs during the systemic administration of certain drugs. As a result, there is no approved pharmacological treatment for periprosthetic osteolysis thus far. Therefore, gene therapy, instead of drug therapy, targeting inflammatory factors may provide a therapeutic approach with which to avoid the side-effects of anti-inflammatory drugs during long-term systemic administration.

Gene therapy has been applied to the field of orthopedics. Clinical trials have already been initiated for arthritis and the aseptic loosening of prosthetic joints, and the development of bone-healing applications is at an advanced, pre-clinical stage (74). Orthopedic gene therapy originated during the early 1990 s to deliver genes to joints $(75,76)$. The aim is to engineer intra- and peri-articular tissus to synthesize antiarthritic gene products, thereby providing a sustained, local therapy for individual arthritic joints. This approach is attractive since joints are discrete, accessible cavities that can be readily injected.

RNAi interference (RNAi) is a standard method for the knockdown of any target gene of interest in vitro, exploring a naturally occurring catalytic mechanism. The downregulation of pathologically relevant genes which are aberrantly expressed in a given disease will offer novel therapeutic approaches. The mechanism behind RNAi involves siRNAs, which are cleaved into the fragments known as siRNA (21-23 nucleotides in length) by the enzyme Dicer (77). siRNA therapeutics have developed rapidly, with ongoing or planned clinical trials, and thus we used this siRNA targeting TNF- $\alpha$ to inhibit titanium particle-induced bone resorption. siRNA delivery in vivo is of critical importance for its implementation.

Adenoviral gene therapy, due to its carrier safety, and the fact that it does not need not to be integrated into the host cell genome, has relative stability and high transfection efficiency (78-80), is currently the most widely used viral vectors. Moreover, RNAi has been applied to the clinical practice for the treatment of cancer, and as shown in our study, recombinant adenovirus (Ad-TNF $\alpha$-siRNA) does not exert toxic effects on RAW264.7 murine macrophage cells (Fig. 1). It is thus clear that its safety is reliable and the method is feasible. Ad-TNF- $\alpha$-siRNA effectively suppressd osteoclast differentiation following exposrure to titanium particles and reduced the inhibitory effect of TNF- $\alpha$ secretion from macrophages activated by titanium particles on osteoblast differentiation, which may be useful for the prevention and/or treatment of osteolysis and aseptic loosening, thus preventing TJA. Our in vitro results revealed that TNF- $\alpha$ promoted osteoclast differentiation by stimulating the expression of RANKL in osteoblasts, and that TNF- $\alpha$ synergizes with RANKL to promote osteoclast differentiation. Furthermore, Ad-TNF- $\alpha$-siRNA effectively suppressed osteoclast differentiation following exposure to titanium particles and may well reduce the inhibitory effect of TNF- $\alpha$ secretion from macrophages activated by titanium particles, thus preventing osteoblast differentiation. Taken together, our data suggest that the downregulation of the expression of TNF- $\alpha$ by Ad-TNF- $\alpha$-siRNA provides a promising therapeutic strategy for the treatment of periprosthetic osteolysis.

Our results also highlight the need for more effective treatment methods. Further evidence of the effect of Ad-TNF- $\alpha$-siRNA on particle-induced osteolysis is required in in vivo experiments on animal models. This would involve the creation of an animal model of aseptic loosening, and would then involve the local administration of an intra-articular injection of recombinant adenovirus in order to detect the effect of recombinant adenovirus on titanium particle-induced proinflammatory cytokine expression and periprosthetic osteolysis. Our data may aid in the continued advances in research for the prevention and/or treatment of particle-induced osteolysis.

\section{Acknowledgements}

This study was supported by the National Natural Science Foundation of China (NSFC, grant no. 81060146).

\section{References}

1. Harris WH: The problem is osteolysis. Clin Orthop Relat Res 311: 46-53, 1995.

2. Goldring SR, Clark CR and Wright TM: The problem in total joint arthroplasty: aseptic loosening. J Bone Joint Surg Am 75: 799-801, 1993.

3. Kadoya Y, Kobayashi A and Ohashi H: Wear and osteolysis in total joint replacements. Acta Orthop Scand Suppl 278: 1-16, 1998.

4. Friedman RJ, Black J, Galante JO, Jacobs JJ and Skinner HB: Current concepts in orthopaedic biomaterials and implant fixation. Instr Course Lect 43: 233-255, 1994. 
5. Harris WH: Wear and periprosthetic osteolysis: the problem Clin Orthop Relat Res 393: 66-70, 2001.

6. Jacobs JJ, Roebuck KA, Archibeck M, Hallab NJ and Glant TT: Osteolysis: basic science. Clin Orthop Relat Res 393: 71-77, 2001.

7. Ingham $\mathrm{E}$ and Fisher $\mathrm{J}$ : The role of macrophages in osteolysis of total joint replacement. Biomaterials 26: 1271-1286, 2005.

8. Hallab NJ and Jacobs JJ: Biologic effects of implant debris. Bull NYU Hosp Jt Dis 67: 182-188, 2009.

9. Kaufman AM, Alabre CI, Rubash HE and Shanbhag AS: Human macrophage response to UHMWPE, TiAlV, $\mathrm{CoCr}$, and alumina particles: analysis of multiple cytokines using protein arrays. J Biomed Mater Res A 84: 464-474, 2008.

10. Liu F, Zhu Z, Mao Y, Liu M, Tang T and Qiu S: Inhibition of titanium particle-induced osteoclastogenesis through inactivation of NFATc1 by VIVIT peptide. Biomaterials 30: 1756-1762, 2009.

11. Shanbhag AS, Jacobs JJ, Black J, Galante JO and Glant TT: Cellular mediators secreted by Interfacial membranes obtained at revision total hip arthroplasty. J Arthroplasty 10: 498-506, 1995.

12. Kimble RB, Srivastava S, Ross FP, Matayoshi A and Pacifici R: Estrogen deficiency increases the ability of stromal cells to support murine osteoclastogenesis via an interleukin-land tumor necrosis factor-mediated stimulation of macrophage colonystimulating factor production. J Biol Chem 271: 28890-28897, 1996.

13. Mori T, Miyamoto T, Yoshida H, Asakawa M, Kawasumi M, Kobayashi T, et al: IL-1 $\beta$ and TNF $\alpha$-initiated IL-6-STAT3 pathway is critical in mediating inflammatory cytokines and RANKL expression in inflammatory arthritis. Int Immunol 23: 701-712, 2011

14. Lacey, DL, Timms E, Tan HL, Kelley MJ, Dunstan CR, Burgess T, Elliott R, et al: Osteoprotegerin (OPG) ligand is a cytokine that regulates osteoclast differentiation and activation. Cell 93: 165-176, 1998.

15. Quinn JM, Elliott J, Gillespie MT and Martin TJ: A combination of osteoclast differentiation factor and macrophage-colony stimulating factor is sufficient for both human and mouse osteoclast formation in vitro. Endocrinology 139: 4424-4427, 1998.

16. Yasuda H, Shima N, Nakagawa N, Yamaguchi K, Kinosaki M, Mochizuki S, et al: Osteoclast differentiation factor is a ligand for osteoprotegerin /osteoclastogenesis- inhibitory factor and is identical to TRANCE/RANKL. Proc Natl Acad Sci USA 95 3597-3602, 1998.

17. Takayanagi H, Ogasawara K, Hida S, Chiba T, Murata S, Sato K, et al: T-cell-mediated regulation of osteoclastogenesis by signalling cross-talk between RANKL and IFN-gamma. Nature 408: 600-605, 2000.

18. Teitelbaum SL: Bone resorption by osteoclasts. Science 289 1504-1508, 2000.

19. Goater JJ, O'Keefe RJ, Rosier RN, et al: Efficacy of ex vivo OPG gene therapy in preventing wear debris induced osteolysis. J Orthop Res 20: 169-173, 2002.

20. Lee SS, Sharma AR, Choi BS, Jung JS, Chang JD, Park S, et al The effect of TNFa secreted from macrophages activated by titanium particles on osteogenic activity regulated by WNT/BMP signaling in osteoprogenitor cells. Biomaterials 33: 4251-4263, 2012.

21. Glass DA II, Bialek P, Ahn JD, Starbuck M, Patel MS, Clevers H Taketo MM, Long F, McMahon AP, Lang RA, et al: Canonical Wnt signaling in differentiated osteoblasts controls osteoclast differentiation. Dev Cell 8: 751-764, 2005.

22. Holmen SL, Zylstra CR, Mukherjee A, Sigler RE, Faugere MC, Bouxsein ML, et al: Essential role of beta-catenin in postnatal bone acquisition. J Biol Chem 280: 21162-21168, 2005.

23. Grimaud E, Soubigou L, Couillaud S, Coipeau P, Moreau A, Passuti N, et al: Receptor activator of nuclear factor kappaB ligand (RANKL)/osteoprotegerin (OPG) ratio is increased in severe osteolysis. Am J Pathol 163: 2021-2031, 2003.

24. Gori F, Hofbauer L, Dunstan CR, Spelsberg TC, Khosla S and Riggs BL: The expression of osteoprotegerin and RANK ligand and the support of osteoclast formation by stromal-osteoblast lineage cells is developmentally regulated. Endocrinology 141: 4768-4776, 2000.

25. Yao Z, Li P, Zhang Q, et al: Tumor necrosis factor-increases circulating osteoclast precursor numbers by promoting their proliferation and differentiation in the bone marrow through up-regulation of c-Fms expression. J Biol Chem 281: 11846-11855, 2006.
26. Zhang YH, Heulsmann A, Tondravi MM, et al: Tumor necrosis factor-alpha (TNF) stimulates RANKL-induced osteoclastogenesis via coupling of TNF type 1 receptor and RANK signaling pathways. J Biol Chem 276: 563-568, 2001.

27. Abu-Amer Y: Advances in osteoclast differentiation and function. Curr Drug Targets Immune Endocr Metabol Disord 5: 347-355, 2005.

28. Teitelbaum S: Bone resorption by osteoclasts. Science 289 : 1504-1508, 2000.

29. Yamashita T, Yao Z, Li F, et al: NF-kappaB p50 and p52 regulate receptor activator of NF-kappaB ligand (RANKL) and tumor necrosis factor-induced osteoclast precursor differentiation by activating c-Fos and NFATc1. J Biol Chem 282: 18245-18253, 2007.

30. Boyce BF and Xing L: Functions of RANKL/RANK/OPG in bone modeling and remodeling. Arch Biochem Biophys 473: 139-146, 2008.

31. Yao Z, Xing L and Boyce BF: NF- $\kappa$ B p100 limits TNF-induced bone resorption in mice by a TRAF3-dependent mechanism. J Clin Invest 119: 3024-3034, 2009.

32. Fullerb K and Murphy C: TNF alpha potently activates osteoclasts, through a direct action independent of and strongly synergistic with RANKL. Endocrinology 143: 1108-1118, 2002.

33. Kobayashi K, Takahashi N, Jimi E, Udagawa N, Takami M, Kotake $\mathrm{S}$, et al: Tumor necrosis factor alpha stimulates osteoclast differentiation by a mechanism independent of the ODF/ RANKL-RANK interaction. J Exp Med 191: 275-286, 2000.

34. Gallo J, Raska M, Mrazek F and Petrek M: Bone remodeling, particle disease and individual susceptibility to periprosthetic osteolysis. Physiol Res 57: 339-349, 2008.

35. Hikiji H, Shin WS, Koizumi T, Takato T, Susami T, Koizumi Y, et al: Peroxynitrite production by TNF-alpha and IL-1beta: implication for suppression of osteoblastic differentiation. Am J Physiol Endocrinol Metab 278: E1031-E1037, 2000.

36. Gilbert L, He X, Farmer P, Boden S, Kozlowski M, Rubin J, et al: Inhibition of osteoblast differentiation by tumor necrosis factor-alpha. Endocrinology 141: 3956-3964, 2000.

37. Kurokouchi K, Kambe F, Yasukawa K, Izumi R, Ishiguro N Iwata $\mathrm{H}$ and Seo H: TNF-alpha increases expression of IL-6 and ICAM-1 genes through activation of NF-kappaB in osteoblastlike ROS17/2.8 cells. J Bone Miner Res 13: 1290-1299, 1998.

38. Abu-Amer Y, Ross FP, Edwards J and Teitelbaum SL: Lipopolysaccharide-stimulated osteoclastogenesis is mediated by tumor necrosis factor via its P55 receptor. J Clin Invest 100: $1557-1565,1997$.

39. Abu-Amer Y, Ross FP, McHugh KP, Livolsi A, Peyron JF and Teitelbaum SL: Tumor necrosis factor- $\alpha$ activation of nuclear transcription factor $-\kappa \mathrm{B}$ in marrow macrophages is mediated by c-Src tyrosine phosphorylation of I $\mathrm{B} \alpha$. J Biol Chem 273: 29417-29423, 1998.

40. Kudo O, Fujikawa Y, Itonaga I, Sabokbar A, Torisu T and Athanasou NA: Proinflammatory cytokine (TNF-alpha/ IL-1alpha) induction of human osteoclast formation. J Pathol 198: 220-227, 2002.

41. Rakshit DS, Ly K, Sengupta TK, Nestor BJ, Sculco TP, Ivashkiv LB and Purdue PE: Wear debris inhibition of anti-osteoclastogenic signaling by interleukin- 6 and interferongamma. Mechanistic insights and implications for periprosthetic osteolysis. J Bone Joint Surg Am 88: 788-799, 2006.

42. von Knoch M, Jewison DE, Sibonga JD, Sprecher C, Morrey BF, Loer F, et al: The effectiveness of polyethylene versus titanium particles in inducing osteolysis in vivo. J Orthop Res 22: 237-243, 2004.

43. Lee SS, Woo CH, Chang JD and Kim JH: Roles of Rac and cytosolic phospholipase A2 in the intracellular signalling in response to titanium particles. Cell Signal 15: 339-345, 2003.

44. Zheng H, Yu X, Collin-Osdoby P and Osdoby P: RANKL stimulates inducible nitricoxide synthase expression and nitric oxide production in developing osteoclasts. An autocrine negative feedback mechanism triggered by RANKL induced interferonbeta via NF-kappaB that restrains osteoclastogenesis and bone resorption. J Biol Chem 281: 15809-15820, 2006.

45. Asagiri $\mathrm{M}$ and Takayanagi $\mathrm{H}$ : The molecular understanding of osteoclast differentiation. Bone 40: 251-264, 2007.

46. Takayanagi H: The role of NFAT in osteoclast formation. Ann NY Acad Sci 1116: 227-237, 2007.

47. Takayanagi H, Kim S, Koga T, Nishina H, Isshiki M, Yoshida H, et al: Induction and activation of the transcription factor NFATc1 (NFAT2) integrate RANKL signaling in terminal differentiation of osteoclasts. Dev Cell 3: 889-901, 2002. 
48. Taki N, Tatro JM, Lowe R, Goldberg VM and Greenfield EM: Comparison of the roles of IL-1, IL-6, and TNF- $\alpha$ in cell culture and murine models of aseptic loosening. Bone 40: 1276-1283, 2007.

49. Yamanaka Y, Abu-Amer W, Foglia D, Otero J, Clohisy JC and Abu-Amer Y: NFAT2 is an essential mediator of orthopedic particle-induced osteoclastogenesis. J Orthop Res 26: 1577-1584 2008.

50. Lam J, Takeshita S, Barker JE, Kanagawa O, Ross FP and Teitelbaum SL: TNF-alpha induces osteoclastogenesis by direct stimulation of macrophages exposed to permissive levels of RANK ligand. J Clin Invest 106: 1481-1488, 2000.

51. Matsuo K, Galson DL, Zhao C, Peng L, Laplace C, Wang KZ, et al: Nuclear factor of activated T-cells (NFAT) rescues osteoclastogenesis in precursors lacking c-Fos. J Biol Chem 279: 26475-26480, 2004.

52. Hofbauer LC, Lacey DL, Dunstan CR, Spelsberg TC, Riggs BL and Khosla S: Interleukin-1beta and tumor necrosis factoralpha, but not interleukin-6, stimulate osteoprotegerin ligand gene expression in human osteoblastic cells. Bone 25 255-259, 1999.

53. Crotti TN, Smith MD, Findlay DM, Zreiqat H, Ahern MJ, Weedon $\mathrm{H}$, et al: Factors regulating osteoclast formation in human tissues adjacent to peri-implant bone loss: expression of receptor activator NFkappaB, RANK ligand and osteoprotegerin. Biomaterials 25: 565-573, 2004.

54. Arai F, Miyamoto T, Ohneda O, Inada T, Sudo T, Brasel K, Miyata $\mathrm{T}$, et al: Commitment and differentiation of osteoclas precursor cells by the sequential expression of c-Fms and receptor activator of nuclear factor kappaB (RANK) receptors. J Exp Med 190: 1741-1754, 1999.

55. Bucay N, Sarosi I, Dunstan CR, Morony S, Tarpley J, Capparelli C, et al: Osteoprotegerin-deficient mice develop early onset osteoporosis and arterial calcification. Genes Dev 12: 1260-1268, 1998.

56. Burgess TL, Qian Y, Kaufman S, Ring BD, Van G, Capparelli C, et al: The ligand for osteoprotegerin (OPGL) directly activates mature osteoclasts. J Cell Biol 145: 527-538, 1999.

57. Nakagawa N, Kinosaki M, Yamaguch K, Shima N, Yasuda $H$, Yano $\mathrm{K}$, et al: RANK is the essential signaling receptor for osteoclast differentiation factor in osteoclastogenesis. Biochem Biophys Res Commun 253: 395-400, 1998.

58. Purdue PE, Koulouvaris P, Nestor BJ and Sculco TP: The central role of wear debris in periprosthetic osteolysis. HSS J 2: 102-113, 2006.

59. Tanaka Y, Nakayamada S and Okada Y: Osteoblasts and osteoclasts in bone remodeling and inflammation. Curr Drug Targets Inflamm Allergy 4: 325-328, 2005.

60. Peruzzi B, Cappariello A, Del Fattore A, Rucci N, De Benedetti F and Teti A: c-Src and IL-6 inhibit osteoblast differentiation and integrate IGFBP5 signalling. Nat Commun 3: 630, 2012.

61. Abbas S, Zhang YH, Clohisy JC and Abu-Amer Y: Tumor necrosis factor-alpha inhibits pre-osteoblast differentiation through its type-1 receptor. Cytokine 22: 33-41, 2003.

62. Harada S and Rodan GA: Control of osteoblast function and regulation of bone mass. Nature 423: 349-355, 2003.

63. Kramer I, Halleux C, Keller H, Pegurri M, Gooi JH, Weber PB, et al: Osteocyte Wnt/beta-catenin signaling is required for normal bone homeostasis. Mol Cell Biol 30: 3071-3085, 2010.
64. Kamiya N, Ye L, Kobayashi T, et al: BMP signaling negatively regulates bone mass through sclerostin by inhibiting the canonical Wnt pathway. Development 135: 3801-3811, 2008.

65. Thomas GP, Baker SU, Eisman JA and Gardiner EM: Changing RANKL/OPG mRNA expression in differentiating murine primary osteoblasts. J Endocrinol 170: 451-460, 2001

66. Sabokbar A and Rushton N: Role of inflammatory mediators and adhesion molecules in the pathogenesis of aseptic loosening in total hip arthroplasties. J Arthroplasty 10: 810-816, 1995.

67. Kim KJ, Rubash HE, Wilson SC, D'Antonio JA and McClain EJ: A histologic and biochemical comparison of the interface tissues in cementless and cemented hip prostheses. Clin Orthop Relat Res 287: 142-152, 1993.

68. Al-Saffar N, Khwaja HA, Kadoya Y and Revell PA: Assessment of the role of GM-CSF in the cellular transformation and the development of erosive lesions around orthopaedic implants. Am J Clin Pathol 105: 628-639, 1996.

69. Wang W, Ferguson DJ, Quinn JM, Simpson AH and Athanasou NA: Biomaterial particle phagocytosis by boneresorbing osteoclasts. J Bone Joint Surg Br 79: 849-856, 1997.

70. Gallo J, Kamínek P, Tichá V, Riháková P and Ditmar R: Particle disease. A comprehensive theory of periprosthetic osteolysis: a review. Biomed Pap Med Fac Univ Palacky Olomouc Czech Repub 146: 21-28, 2002.

71. Archibeck MJ, Jacobs JJ, Roebuck KA and Glant TT: The basic science of periprosthetic osteolysis. Instr Course Lect 50: 185-195, 2001.

72. Schwarz E, Lu P, Goater J, Benz E, Kollias G, Rosier R, et al: Tumor necrosis factor-alpha/nuclear transcription factor-kappaB signaling in periprosthetic osteolysis. J Orthop Res 18: 472-480, 2000.

73. Xu JW, Konttinen YT, Lassus J, Natah S, Ceponis A, Solovieva S, et al: Tumor necrosis factor-alpha (TNF-alpha) in loosening of total hip replacement (THR). Clin Exp Rheumatol 14: 643-648, 1996.

74. Evans $\mathrm{CH}$, Ghivizzani SC and Robbins PD: Orthopedic gene therapy in 2008. Mol Ther 17: 231-244, 2009.

75. Bandara G, Robbins PD, Georgescu HI, Mueller GM, Glorioso, JC and Evans $\mathrm{CH}$ : Gene transfer to synoviocytes: prospects for gene treatment of arthritis. DNA Cell Biol 11: 227-231, 1992.

76. Bandara G, Mueller GM, Galea-Lauri J, Tindal $\mathrm{MH}$ Georgescu HI, Suchanek, MK et al: Intraarticular expression of biologically active interleukin 1-receptor-antagonist protein by ex vivo gene transfer. Proc Natl Acad Sci USA 90: 10764-10768, 1993.

77. Bernstein E, Caudy AA, Hammond SM and Hannon GJ: Role for a bidentate ribonuclease in the initiation step of RNA interference. Nature 409, 363-366, 2001.

78. Bao JJ, Zhang WW and Kuo MT: Adenoviral delivery of recombinant DNA into transgenic mice bearing hepatocellular carcinomas. Hum Gene Ther 7: 355-365, 1996.

79. Ali M, Lemoine NR and Ring CJ: The use of DNA viruses as vectors for gene therapy. Gene Ther 1: 367-384, 1994.

80. Smith AE: Viral vectors in gene therapy. Annu Rev Microbiol 49: $807-838,1995$ 